\title{
Water Economy Balance of the Almaty City
}

\author{
Alexander G. Chigrinets ${ }^{1 *}$, Lidiya P. Mazur ${ }^{2}$, Kassym K. Duskayev ${ }^{1}$, \\ Larissa Y. Chigrinets ${ }^{1}$, Saniya T. Akhmetova ${ }^{1}$ \\ 1 Department of meteorology and hydrology, Al-Farabi Kazakh National University, Almaty, Kazakhstan \\ 2 Ecology Problems Research Institute at Al-Farabi Kazakh National University, Almaty, Kazakhstan \\ * Corresponding author's e-mail: ch.al.georg@mail.ru
}

\begin{abstract}
This article provides and analyses the detailed water balances of the Almaty city in regards to the water resources, the share of which for different water bodies is $50 \%, 75 \%$ or $95 \%$ at the present level of surface and groundwater use. We have quantitatively assessed such surface water resources for specific water bodies and for the whole city. We have analysed the field studies of channel water balances of small rivers conducted in 2006, 2007 and 2013 (Almaty city) to identify the areas of abstraction losses and groundwater outcrop in riverbeds. The water balance analysis shows that Almaty city suffers from significant deficits in water resources. On the basis of the population growth dynamics, we assume that it will only increase. We have clarified the methods for calculating hydrometeorological characteristics and gained the updated information about the stream flows in a number of control sections and the channel water balances of the Karasu.
\end{abstract}

Keywords: mountain sources, Karasu (rivers), intra-annual flow distribution, water resources, evaporation, irrigation

\section{INTRODUCTION}

Providing urban territory with industrial and drinking water is a main part of hydrology. The water balance studies are focused on quantitative water resource assessment in a particular economic area or river basin [Charalambous, Bruggeman, Lange, 2012]. They are designed for rational and scientifically substantiated water management. Water balance is used in water resources management and during the process of developing the diagrams of water resources use and protection [Comair et al., 2014]. Water scarcity is a global problem: $97 \%$ of all water resources of the planet are the oceans and seas, and only 3\% corresponds to fresh water, which is also quite difficult to use, as it is trapped in the form of ice, soil moisture, and groundwater [Bacon, 2009]. More than a half of fresh water is concentrated in glaciers. The conflict between the rapid growth of consumption and the unchanged volume of water is the main reason standing behind the lack of water.
The accelerated growth in water consumption is determined by the global economic growth and the food crises in many countries [Berg, 2015].

Therefore, about 60 UNESCO states carry out scientific research to update their own data on water resources and exchange the experience on optimal and integrated use of natural waters based on a single program. The principles and guidelines of water balance analysis are universal [Fowe et al., 2015; Rushforth, Adams, Ruddell, 2013; Tsoukalas, Makropoulos, 2015]. However, the studies on the problems of urban hydrology and the procedure of drawing up water balances are contradictory [Paterson et al., 2015; Ruddell et al., 2014].

As the urban population grows, the problems of rational and integrated use of water resources and their territorial redistribution are aggraveted. This issue is particularly relevant when it comes to mountain and foothill areas, the environment of which is difficult for the water flow formation and where the largest city of the Republic of Kazakhstan - Almaty - is located. 
The Almaty city is located at the bottom of the northern slope of the Trans-Ili Alatau ridge - one of the spurs of the mountain range of the northern Tien Shan. The average height of the city is 800 meters above the sea. It is a large scientific, cultural, financial and industrial center [Rawaf, De Maeseneer, Starfield, 2008].

In Almaty, small rivers annualy attract more and more attention, as their water is widely used for household and drinking purposes, irrigation, industry, power generation, recreation and other purposes. The health and well-being of the urban population depends on their ecological state. Karasu is an important source of water balance in Almaty. These are small rivers fed by the groundwater egress in the foothills and mountain valleys. The first description of an annual stream flow in this region was made in 1965 [Arhonditsis et al., 2006]. A detailed hydrological map was prepared while the Big Almaty Channel was designed [Ospanov, Myrzakhmetov, Zholguttiyev, 2015] and the project of river channel improvement was developed for Malaya and Bolshaya Almatinka, and Esentai [Mynbaeva, 2016]. Water Management Assessment in Almaty is a part of the ecological safety program in Kazakhstan [Dahl, Kuralbayeva, 2001]. The almaty territory is constantly expanding. Over the past six years, its territory has increased significantly. The urban population has also grown. These changes directly affect the volume of water consumption in urban areas.

The relevance of the research topic is determined by constantly growing water consumption and reducing water resources of rivers that cross the territory of Almaty city on the back of developing sectors of industrial production, growing municipal urban management needs, growing population and territory etc.

The purpose of this study is to quantitatively assess the hydrological characteristics of teritorial water bodies under modern conditions; to assess water resources, provide and analyze the water balance of the Almaty city. We have considered the studies regarding the water balance of the river channels that crossing the territory of the city.

\section{MATERIALS AND METHODS}

The water balances for the Almaty city are drawn up in regards to water resources, the share of which for different water bodies is $50 \%, 75 \%$ or $95 \%$ at the present level of water resources security. We have chosen the following intervals for calculations - months and years. Selected groundwater volume as part of water economic balance, as well as its other components, was taken according to the state statistical reporting, or was obtained by the calculation method. The regulating releases for channels were fixed according to the procedures [Nouiri et al., 2015; Ouyang et al., 2014].

Total water resources of the Almaty city involve the stream flow and drainage basins covering the territory. The control section with the highest water content was selected for calculations. In different periods (different water content), total water resources are calculated through the total runoff, the share of which is equal for the rivers passing the studied territory. In determining the water resources of the Almaty city, we have calculated the water resources of major rivers (Malaya Almatinka, Bolshaya Almatinka, Karagaly) that cross the urban area and mountain sources (Abylgaziev, Botbaysay, Tiksay, Terisbulak, Kerenkulak, Boroldai et al.) feeding the major rivers and water resources of Karasu (Ashchibulak, Terenkara, Sultanka, Moyka, Karasu-Turksib, Boroldai, Dzhigitovka et al.) and forming a flow within the urban area.

Bolshaya Almatinka water resources were calculated through the total runoff, the share of which is equal for the control sections of the Bolshaya Almatinka $-2 \mathrm{~km}$ higher up the Prohodnaya river mouth and Terisbutak river mouth; for the Karagaly river - in the control section of the river passing the Chapaev Kolkhoz, and for the Aksai river - in the control section of the river passing the Kordon Aksay.

Selected groundwater volume as part of the water balance is of 191058 thousand $\mathrm{m}^{3}$, including the groundwater from the Almaty ba$\sin \left(125.645\right.$ thousand $\mathrm{m}^{3}$ ) and the groundwater from the Talgarsky basin transferred to the Almaty basin (61777 thousand $\mathrm{m}^{3}$ according to the Balkhash-Alakol Basin Water Agency (BABWA). Besides the surface flow, water balance involves precipitation, water outcrop in riverbeds and utilized sewage (7114 thousand $\mathrm{m}^{3}$, according to BABWA) .

The data on precipitation are used by weather stations of Almaty, which height (847 m BS) is close to the average height of the city ( $800 \mathrm{~m} \mathrm{BS})$.

The values of water outcrop in the channels of major rivers (Malaya Almaty, Bolshaya Almaty and Karagaly) and channel losses were 
taken mainly based on the results of the channel water balance measurements carried out on the territory of Almaty in 2005, 2006 and 2012 [Chigrinets, 2006; Chigrinets, Dolbeshkin, 2012; Chigrinets, Duskaev, 2005].

While conducting the research, attention was paid to the channel balance of the major rivers: the Malaya Almatinka with the the Esentai River arm, the Bolshaya Almatinka and the Kargaly; Karasu: in the Bolshaya Almatinka basin - the Boroldai River and the Dzhigitovka River; in the Malaya Almatinka basin - the Ashchibulak, Terenkara, Sultan-Karasu, Moyka (Moyka-Karasu), Karasu-Turksib rivers, as well unnamed rivers feeding the Malaya Almatinka River.

We have already noted that the study of channel water balance of the Almaty rivers was conducted in 2006, 2007 and 2013 to identify and clarify the abstraction losses and and groundwater outcrop, as well as to identify how their values change over time. The hydrometric measurements were conducted to measure abstraction losses (or increment) in the typical areas with the Water Flow Velocity Meter ISVP-GR-21M1 (Aneroid, Russia).

The channel water balance was calculated within the city boundaries with the techniques described below. The control section length for major rivers ranged from $8.72 \mathrm{~km}$ (Kargaly) to $34.1 \mathrm{~km}$ (Esentai); for Karasu - from $7.27 \mathrm{~km}$ (unnamed rivers (release at the Kazakh natural acclimatization station (KazNAS)) to $16.2 \mathrm{~km}$ (Boroldai) (see Table 1). Total summer evaporation is calculated by the method described in [Starke et al., 2011].

We selected the following equations to analyze the field studies and calculate the CWB of small rivers:

1) for abstraction losses in unconsolidated sediments of river fan:

$$
S_{a}=Q_{u p}+Q_{d i s}-Q_{1}-Q_{\text {in }}+Q_{v s}
$$

where: $S_{\mathrm{a}}-$ absolute abstraction losses, $\mathrm{m}^{3} / \mathrm{s}$;

$Q_{u p}$ and $\mathrm{Q}_{1}-$ river discharge in the higher and lower control sections, respectively, $\mathrm{m}^{3} / \mathrm{s}$;

$Q_{\text {dis }}$ - total inflow discharge, $\mathrm{m}^{3} / \mathrm{s}$;

$Q_{\text {in }}$ - total intake, $\mathrm{m}^{3} / \mathrm{s}$;

$Q_{\text {ret }}-$ total river discharge in regards to the surface water returned into the river from disposal fields and other discharges, $\mathrm{m}^{3} / \mathrm{s}$;
Table 1. Length of the studied sections of the channel water balance (CWB) of small rivers of the Almaty city

\begin{tabular}{|l|l|l|}
\hline No & River & $\begin{array}{l}\text { Length of } \\
\text { CWB, } \mathrm{km}\end{array}$ \\
\hline \multicolumn{2}{|l|}{ Major rivers (with arms) } & 8.72 \\
\hline 1 & Kargaly & 30.1 \\
\hline 2 & Bolshaya Almatinka & 26.0 \\
\hline 3 & Malaya Almatinka & 34.1 \\
\hline 4 & $\begin{array}{l}\text { Esentai (Vesnovka) - left arm of the } \\
\text { Malaya Almatinka }\end{array}$ & 18.8 \\
\hline 5 & $\begin{array}{l}\text { Zharbulak (Kazachka) - right arm of the } \\
\text { Malaya Almatinka }\end{array}$ & 16.2 \\
\hline Karasu & 11.2 \\
\hline 1 & Borolday (Burunday) & 15.9 \\
\hline 2 & $\begin{array}{l}\text { Dzhigitovka (with a pond system of the } \\
\text { JSC BENT) }\end{array}$ & 14.7 \\
\hline 3 & Moyka (Moyka-Karasu) & 8.55 \\
\hline 4 & Sultanka (Sultan-Karasu) & 8.55 \\
\hline 5 & Aschibulak & 12.3 \\
\hline 6 & Terenkara & 7.27 \\
\hline 7 & Karasu (Karasu-Turksib) & 7.85 \\
\hline 8 & Unnamed Karasu & \\
\hline 9 & $\begin{array}{l}\text { Sarybulak (right bank feeder of the } \\
\text { Malaya Almatinka) }\end{array}$ & \\
\hline & &
\end{tabular}

2) for groundwater outcrop into the Karasu channels:

$$
S_{g r}=Q_{1}-Q_{u p}+Q_{\text {in }}-Q_{\text {dis }}-Q_{v s}
$$

where: $S_{g r}-$ absolute groundwater outcrop, $\mathrm{m}^{3} / \mathrm{s}$.

On the selected balance areas, measurements were performed in rainless periods. We took into account the time lag and measurement errors.

In order to compare the channel water balances of various rivers, we did not apply the absolute values, but rather the values of specific abstraction losses $\left(\mathrm{Sl}_{\mathrm{a}} \mathrm{m}^{3} / \mathrm{s} \times \mathrm{km}\right)$ and discharge outcrops $\left(\mathrm{Sl}_{\mathrm{gr}} \mathrm{m}^{3} / \mathrm{s} \times \mathrm{km}\right)$ per unit of river section length:

$$
S l_{a}=\frac{Q u p+Q d i s-Q l-Q i n+Q r e t}{L}
$$

$$
S l_{g r}=\frac{Q l-Q u p+Q i n-Q d i s-Q r e t}{L}
$$

where: $L$ - length of the measured water balance section, $\mathrm{km}$. The remaining symbols are the same.

The sample was considered as valid while assessing the results by Student's t-test, Fisher's exact test and Wilcoxon signed-rank test, at $\mathrm{p}<0.05$. The statistical data was analyzed with the Statistica 6.0 (StatSoft, USA) software package. 


\section{RESULTS}

The analysis of the integral curves of major river runoff in the area shows an increase in the volume of water intakes. This has affected the water content in the control sections. Since cadastral materials did not provide precise information about the water intakes for municipal purposes in recent years, the stream flow in the control sections can be considered like in households (see Figure 1). In this regard, we used the data on the relatively natural flow period to determine the water resources of the major river flows: for the Malaya Almatinka - before 1973, for the Bolshaya Almatinka - before 1989, for the Aksai before 2000 .

We also recorded a trend of increasing runoff from the mid-80s due to global warming, degradation of the glaciation of the northern slope of the Trans-Ili Alatau, and accordingly, the increase of glacier runoff component (see Figure 2).
The results of the calculation regarding surface water resources, located on the territory of the Almaty city, as a runoff volume which share for different water bodies is $50 \%$, are given in the Table 2.

The analysis of the calculation results regarding CWB of the major rivers and Karasu showed that the outcorp area of Karasu is lower than the level of $540 \mathrm{~m}$ BS both in the Bolshaya Almatinka River Basin and in the Malaya Almatinka River Basin.

According to the research results, there is a gradual decrease in the Karasu runoff. The areas of groundwater outcorp shift to the north (higher) and the values of the absolute groundwater outcorp decreased due to an increase in the water intakes from Almaty and Burundaisk water deposits. The latter led to an overall decrease in the groundwater level and the abstraction losses since the major river channels were concreted. These losses feed the groundwater by carrying water
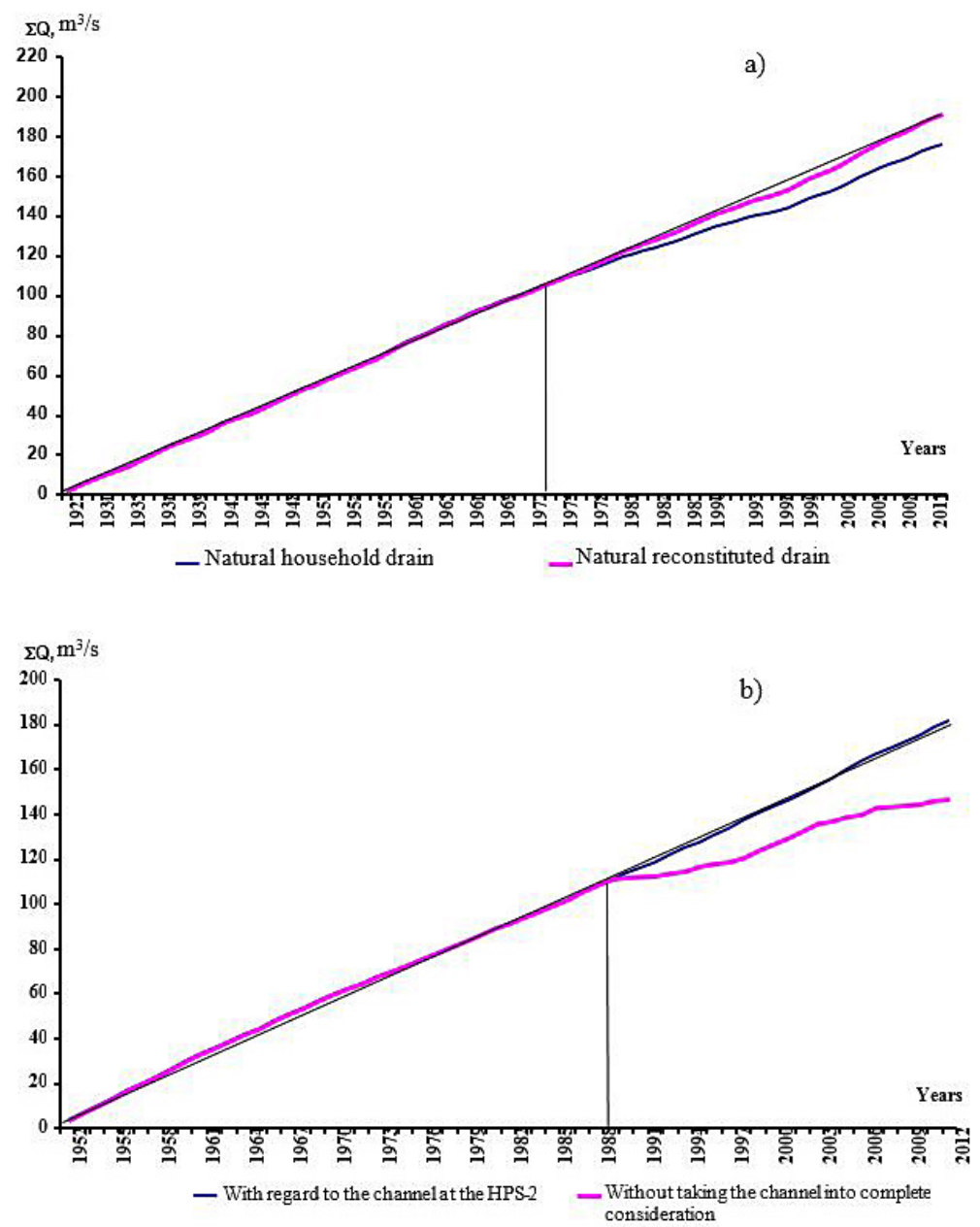

Fig. 1. The integral curves of runoff of major river in the control sections - Malaya Almatinka (Almaty) (a) and Bolshaya Almatinka (2 km higher up the Prohodnaya river mouth. Intra-annual flow distribution (b) for the entire period of stationary observations 

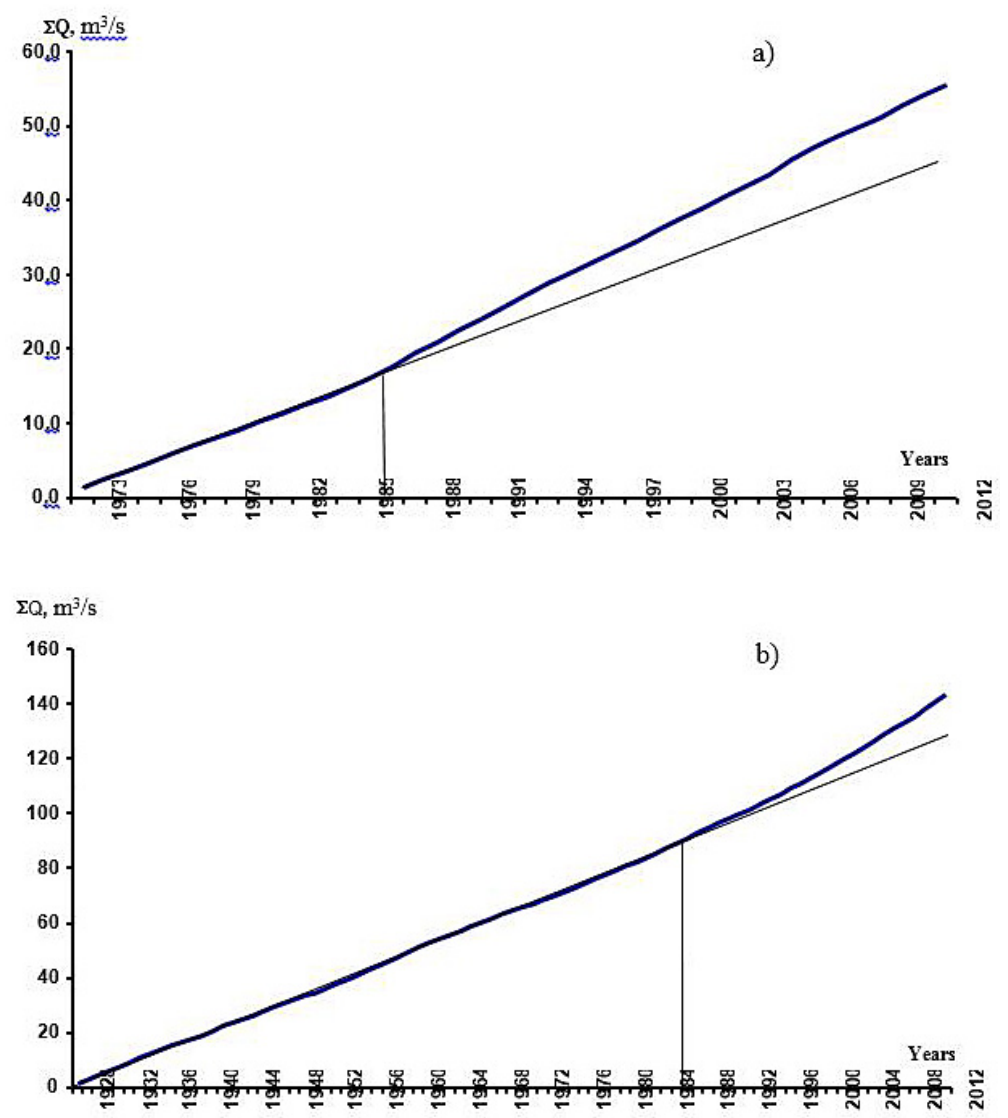

Fig. 2. The integral curves of runoff of major rivers in the control sections higher up the major water catchment areas: Malaya Almatinka - below the Sarysay river mouth (a); Bolshaya Almatinka - $1.1 \mathrm{~km}$ above the Bolshoe Almatinskoe lake (b) for the entire period of stationary observations

exchange and maintaining both a stable Karasu flow and their environmental safety.

The Karasu channel development and cleaning entailed the groundwater outflow normalization, as well as the improvement of the urban river system, its recreation ability. This is beneficial to the ecological state of the rivers and surrounding areas.

According to our data, the annual precipitation involves about $38.9 \%\left(71.033 .6\right.$ thousand $\left.\mathrm{m}^{3}\right)$ of water evaporated from the territory of Almaty city, $0.6 \%\left(1133.34\right.$ thousand $\left.\mathrm{m}^{3}\right)$ - from the water surface, and $60.5 \%\left(110.687 .7\right.$ thousand $\left.\mathrm{m}^{3}\right)-$ from snow in winter and from the ground surface in summer after raining.

The environmental flow includes the flow of Karasu and mountain sources. The water balance calculation was made in three versions: for water resources, the share of which for different water bodies is $50 \%, 75 \%$ or $95 \%$. Table 3 shows the results of water balance calculation for the year that is average in terms of water content (share of water resourses is $50 \%$ ).

\section{DISCUSSION}

The analysis of water balance calculation showed that there are significant deficits of water in the Almaty city. The overall balance is positive, as the share of water resources is $50 \%$. There is a minor water shortage in the basins of some rivers (like Malaya Almatinka) in the period from July to October, as well as in the Karagaly river basin throughout the year. Water scarcity is recorded only in September $\left(2\right.$ million $\left.\mathrm{m}^{3}\right)$. However, the overall balance is negative in the years when the share of water resources is $75 \%$. There are problems with water consumption across the whole territory of the city ( 6 months -8.1 million $\left.\mathrm{m}^{3}\right)$. If the share of water resources is $95 \%$, problems with water consumption can be recorded throughout the year $\left(63.3\right.$ million $\left.\mathrm{m}^{3}\right)$. On the basis of the population growth dynamics and the increasing number of business entities, we assume that water deficit will continue to grow.

Prudent use of water resources requires strict control of the water intake by registering water 
Table 2. Surface water resources of the Malaya Almatinka, Bolshaya Almatinka, Aksay and Karagaly river basins within the territory of the Almaty city, share of water resourses is $50 \%$, thousand $\mathrm{m}^{3}$

\begin{tabular}{|c|c|c|c|c|c|c|c|c|c|c|c|c|c|}
\hline \multirow{2}{*}{ River-post } & \multicolumn{12}{|c|}{ Months } & \multirow{2}{*}{ Year } \\
\hline & 1 & 2 & 3 & 4 & 5 & 6 & 7 & 8 & 9 & 10 & 11 & 12 & \\
\hline \multicolumn{14}{|c|}{ Malaya Almatinka River Basin } \\
\hline $\begin{array}{l}\text { Malaya } \\
\text { Almatinka - } \\
\text { Almaty }\end{array}$ & 3273.2 & 2594.9 & 3255.4 & 4760.0 & 8431.9 & 9786.8 & 10966.9 & 9125.7 & 5706.8 & 4616.2 & 3890.6 & 3557.8 & 69966.2 \\
\hline \multicolumn{14}{|c|}{ Water resources of mountain sources } \\
\hline $\begin{array}{l}{ }^{*} \text { Abylgaziev - } \\
\text { Almaty }\end{array}$ & 42.9 & 38.7 & 53.6 & 142.6 & 107.1 & 119.2 & 104.5 & 88.4 & 75.2 & 77.7 & 72.6 & 58.9 & 981.4 \\
\hline $\begin{array}{l}\text { * Botbaysay - } \\
\text { Almaty }\end{array}$ & 37.5 & 33.9 & 45.5 & 124.4 & 93.7 & 103.7 & 91.1 & 77.7 & 64.8 & 67.0 & 62.2 & 50.9 & 852.4 \\
\hline Tikksai - Almaty & 155.3 & 140.3 & 200.9 & 518.4 & 401.8 & 440.6 & 401.8 & 321.4 & 285.1 & 294.6 & 259.2 & 222.3 & 3641.7 \\
\hline $\begin{array}{l}\text { Mokry klyuch - } \\
\text { river mouth }\end{array}$ & 24.1 & 21.8 & 32.1 & 44.1 & 50.9 & 38.9 & 34.8 & 29.5 & 25.9 & 26.8 & 25.9 & 24.1 & 378.9 \\
\hline $\begin{array}{l}\text { Teris Bulak } \\
\text { - san. Kam. } \\
\text { Plateau }\end{array}$ & 48.2 & 41.1 & 88.4 & 168.5 & 171.4 & 129.6 & 104.5 & 91.1 & 80.4 & 85.7 & 72.6 & 56.2 & 1137.7 \\
\hline $\begin{array}{l}{ }^{*} \text { Kerenkulak - } \\
\text { river mouth }\end{array}$ & 112.5 & 91.9 & 158.0 & 370.7 & 487.5 & 386.2 & 265.2 & 203.6 & 165.9 & 163.4 & 132.2 & 117.8 & 2654.9 \\
\hline \multicolumn{14}{|c|}{ Water resources of Karasu } \\
\hline $\begin{array}{l}\text { Aschibulak - } \\
\text { Karasu }\end{array}$ & 750.0 & 701.6 & 803.5 & 777.6 & 803.5 & 855.4 & 776.7 & 750.0 & 751.7 & 776.7 & 699.8 & 696.4 & 9142.9 \\
\hline $\begin{array}{l}\text { West Terenkara } \\
\text {-Alma-Ata }\end{array}$ & 857.1 & 870.9 & 1124.9 & 725.8 & 669.6 & 751.7 & 1098.1 & 803.5 & 907.2 & 1339.2 & 1270.1 & 910.7 & 11328.8 \\
\hline $\begin{array}{l}\text { Moika - river } \\
\text { mouth }\end{array}$ & 348.2 & 338.7 & 455.3 & 466.6 & 482.1 & 414.7 & 482.1 & 482.1 & 414.7 & 428.5 & 388.8 & 348.2 & 5050.0 \\
\hline $\begin{array}{l}\text { Sultanka-Alma- } \\
\text { Ata } 1\end{array}$ & 2785.5 & 2104.7 & 2919.5 & 2825.3 & 2571.3 & 1555.2 & 1660.6 & 1205.3 & 1373.8 & 2169.5 & 2617.9 & 2410.6 & 26199.2 \\
\hline $\begin{array}{l}{ }^{*} \text { Karasu- } \\
\text { Turksib- river } \\
\text { mouth }\end{array}$ & 200.9 & 193.5 & 251.8 & 256.6 & 265.2 & 233.3 & 265.2 & 265.2 & 233.3 & 241.1 & 220.3 & 200.9 & 2827.3 \\
\hline \multicolumn{14}{|c|}{ Bolshaya Almatinka River Basin } \\
\hline $\begin{array}{l}\text { Bolshaya } \\
\text { Almatinka - total }\end{array}$ & 9013.2 & 7290.4 & 7614.3 & 8375.9 & 13149.0 & 21278.6 & 22502.5 & 19174.4 & 13769.5 & 12540.3 & 10867.5 & 10063.3 & 155638.9 \\
\hline \multicolumn{14}{|c|}{ Water resources of Karasu } \\
\hline Boralday & 883.9 & 774.1 & 1419.6 & 985.0 & 1071.4 & 959.0 & 964.2 & 1071.4 & 907.2 & 857.1 & 777.6 & 776.7 & 11447.2 \\
\hline $\begin{array}{l}\text { Dzhigitovka - } \\
\text { Krasnii Trudovik }\end{array}$ & 257.1 & 232.2 & 321.4 & 259.2 & 294.6 & 285.1 & 267.8 & 267.8 & 222.9 & 246.4 & 246.2 & 233.0 & 3133.7 \\
\hline \multicolumn{14}{|c|}{ Kargaly River Basin } \\
\hline $\begin{array}{l}\text { Kargaly - } \\
\text { Chapaev } \\
\text { Kolkhoz }\end{array}$ & 883.9 & 725.8 & 857.1 & 1347.8 & 1419.6 & 2721.6 & 3455.1 & 2383.8 & 1555.2 & 1205.3 & 1036.8 & 1044.6 & 18636.6 \\
\hline \multicolumn{14}{|c|}{ Water resources of mountain sources } \\
\hline $\begin{array}{l}\text { Oyzhaylau - } \\
\text { Kamenka }\end{array}$ & 81.1 & 79.8 & 94.6 & 143.9 & 145.1 & 121.3 & 93.7 & 88.3 & 79.4 & 78.4 & 65.4 & 67.6 & 1138.6 \\
\hline \multicolumn{14}{|l|}{ Aksai River Basin } \\
\hline $\begin{array}{l}\text { Aksay - Aksay } \\
\text { Kordon }\end{array}$ & 2126.4 & 1705.5 & 2197.0 & 3091.0 & 5099.9 & 10468.6 & 15626.3 & 14920.4 & 6139.4 & 3970.5 & 3261.8 & 2735.3 & 71342.1 \\
\hline \multicolumn{14}{|c|}{ Water resources of mountain sources } \\
\hline $\begin{array}{l}\text { Tastybulak - } \\
\text { Aksay }\end{array}$ & 73.6 & 68.9 & 91.9 & 169.1 & 193.1 & 231.4 & 156.3 & 110.3 & 97.9 & 82.8 & 71.2 & 73.6 & 1420.1 \\
\hline $\begin{array}{l}\text { Total: major river } \\
\text { runoff }\end{array}$ & 15296.7 & 12316.6 & 13923.8 & 17574.7 & 28100.4 & 44255.6 & 52550.8 & 45604.3 & 27170.9 & 22332.3 & 19056.7 & 17401 & 315583.8 \\
\hline $\begin{array}{l}\text { Mountain } \\
\text { sources runoff }\end{array}$ & 575.2 & 516.4 & 765 & 1681.7 & 1650.6 & 1570.9 & 1251.9 & 1010.3 & 874.6 & 876.4 & 761.3 & 671.4 & 12205.7 \\
\hline Karasu runoff & 6082.7 & 5215.7 & 7296 & 6296.1 & 6157.7 & 5054.4 & 5514.7 & 4845.3 & 4810.8 & 6058.5 & 6220.7 & 5576.5 & 69129.1 \\
\hline $\begin{array}{l}\text { Total runoff in } \\
\text { Almaty }\end{array}$ & 21954.6 & 18048.7 & 21984.8 & 25552.5 & 35908.7 & 50880.9 & 59317.4 & 51459.9 & 32856.3 & 29267.2 & 26038.7 & 23648.9 & 396918.6 \\
\hline
\end{tabular}


users and building a diagram of their dislocation in the city, as well as by installing relevant meters. New technologies based on the use of plastic pipes and introduced into the systems of municipal water use will significantly reduce the abstraction losses while transporting water by pipes. Currently, their amout is in the range of $23-32 \%$. The previously issued licenses for water use should be revised in the context of the new business environment. One has to avoid using drinking water for technical needs instead of the wastewater. It is required to introduce new operation guidelines and to clarify the operational mode of the Big Almaty Channel (BAC) in the context of the changing social environment and the new business environment. The possible volume of the runoff transferred throught the BAC to Almaty should be calculated to cover the water deficit. There shoild be an additional network of RSE "Kazhydromet" hydrological stations built in order to control the water inflow, water runoff from the urban area and water distribution in the area.

The process of comparing the results of the studied CWB runoff and the water balance with the data given in [Charalambous et al., 2012; Wang et al., 2011; Protasov, 1999] leads to the conclusion that there is not only the refined data, but also completely new information about these characteristics. Its is based on more extensive data for the period up to 2012, obtained by applying the method of field measurements and innovative methods of their high-level processing [Chigrinets, Dolbeshkin, 2012].

We have improved the methods for calculating meteorological characteristics, refined new data on river runoff in different control sections, channel water balances, water resources and water balance of the Almaty city.

The water balances of urban areas are one of the most important, complex and littlestudied problems of modern hydrology [Barros, Isidoro, Aragüés, 2011; Luo et al., 2005; Taghvaeian, Neale, 2011].

International experience analysis shows that the major problems in studying balances are associated with the collection of empirical data on natural river flow and other information particularly while collecting data necessary for water balances calculation in urban areas [Mambretti, Brebbia, 2012].

According to the data presented in a number of studies [Comair et al., 2014; Fowe et al., 2015; Ruddell et al., 2014], restoring gaps in observations made for the natural flow of mountain rivers is one of the very complex problems, as it is difficult to find analog rivers. Wherein, the processes of verifying homogeneity of annual river runoff and determining its statistical characteristics are also a serious problem [Kennedy et al., 2015].

Our calculations show that in the years when the water content is at the average level, total amount of water resources in the Almaty city is about 309082 thousand $\mathrm{m}^{3}$ per year, total used underground water resources -191.058 thousand $\mathrm{m}^{3}$ per year, 61777 thousand $\mathrm{m}^{3}$ of which is the water transfered to the territory of the city from the other basins (Eastern Talgar water deposits). Groundwater outcrop in the river channels 34374 thousand $\mathrm{m}^{3} /$ year (see Table 3).

Collecting the basic data and calculating discharges are the most difficult and time consuming part of the water balance study [Fowe et al., 2015; Nouiri et al., 2015; Rushforth et al., 2013]. First and foremost, this is due to the fact that only the water user's address is often registered when water resources are allocated. It is also difficult to find out how large water users use the water [Seto et al., 2012].

The methods for calculating the water runoff and water balance are universal and complementary [Danilov, Khranovich 2010; Chigrinets, Duskaev, 2005]. We have conducted a long-term monitoring of water runoff of small rivers in Almaty. As a result, we obtained modern data on the runoff characteristics that significantly differ from the data provided in the earlier study [Duskaev, Chigrinets, 2001]. In addition, there is new data on water runoff of the previously unstudied rivers.

The research on the channel balance and runoff of small rivers in the Almaty city should be continued in the future, but with more details on such problem areas as major rivers and Karasu. According to our data, water balance discharges involve:

- surface water and ground water intake for household needs and watering green spaces; for the purposes of industry; hydropower; power system; agriculture (regular irrigation); pond-fish farming;

- abstraction losses during water transportation thought water zones;

- abstraction losses during surface runoff along the channels of major rivers;

- runoff transfer from the city to other basins;

- evaporation from the surface of water bodies: ponds, stream reservoirs, channels of major rivers (apparent evaporation);

- precipitation discharge;

- regulating releases and environmental flow. 
Table 3. Water balance of the territory of Almaty city at the present level, the share of water resources is $50 \%$, thousand $\mathrm{m}^{3}$

\begin{tabular}{|c|c|c|c|c|c|c|c|c|c|c|c|c|c|}
\hline \multirow{2}{*}{ Sources and water users } & \multicolumn{12}{|c|}{ Months } & \multirow{2}{*}{ Year } \\
\hline & 1 & 2 & 3 & 4 & 5 & 6 & 7 & 8 & 9 & 10 & 11 & 12 & \\
\hline \multicolumn{14}{|l|}{ Articles } \\
\hline \multicolumn{14}{|c|}{ 1. Surface water resources (major rivers, mountain sources and Karasu) } \\
\hline $\begin{array}{l}\text { The total surface water } \\
\text { resources in Almaty }\end{array}$ & 18529 & 15260 & 17999 & 19303 & 30531 & 37351 & 40425 & 39351 & 27307 & 23112 & 20791 & 19124 & 309082 \\
\hline \multicolumn{14}{|c|}{ 2. Used groundwater resources of water deposits (MSP Almaty, Gorniy Gigant,,Pokrovsky, Boroldai) } \\
\hline $\begin{array}{l}\text { Total used underground water } \\
\text { resources in Almaty }\end{array}$ & 10773 & 10773 & 10773 & 10773 & 10773 & 10773 & 10774 & 10774 & 10773 & 10773 & 10773 & 10773 & 129281 \\
\hline \multicolumn{14}{|c|}{ 3. Surface water transfer to the territory of Almaty from other basins } \\
\hline Big Almaty Channel (BAC) & - & - & - & - & - & - & - & - & - & - & - & - & 0 \\
\hline \multicolumn{14}{|c|}{ 4. Groundwater transfer to the territory of Almaty from other basins } \\
\hline MSP Eastern Talgar & 5148 & 5148 & 5148 & 5149 & 5148 & 5148 & 5148 & 5148 & 5148 & 5148 & 5148 & 5148 & 61777 \\
\hline $\begin{array}{l}\text { Total surface and } \\
\text { underground: }\end{array}$ & 34450 & 31182 & 33920 & 35225 & 46452 & 53272 & 56347 & 55273 & 43228 & 39033 & 36712 & 35045 & 500140 \\
\hline \multicolumn{14}{|c|}{ 5. Groundwater outcrop along the channels of major rivers: Malaya Almatinka, Vesnovka and Bolshaya Almatinka } \\
\hline Total pinchouts: & 2550 & 2644 & 3084 & 3077 & 3106 & 2903 & 3026 & 3047 & 2734 & 2715 & 3055 & 2433 & 34374 \\
\hline \multicolumn{14}{|c|}{$\begin{array}{l}\text { 6. Precipitation (note: precipitation layer is accepted based on data provided by Almaty UHMS; its height is close to the average height of the city - } \\
800 \mathrm{~m} \mathrm{BS} \text { ) }\end{array}$} \\
\hline A total area of $292.1 \mathrm{~km}^{2}$ & 8471 & 10224 & 19863 & 28918 & 29503 & 16941 & 11392 & 7595 & 8179 & 15773 & 15481 & 10516 & 182855 \\
\hline \multicolumn{14}{|l|}{ 7. Utilized sewage } \\
\hline $\begin{array}{l}\text { Drainage water } \\
\text { (Reusable) }\end{array}$ & 593 & 593 & 593 & 593 & 593 & 593 & 593 & 593 & 593 & 593 & 593 & 593 & 7114 \\
\hline TOTAL INFLOW & 46064 & 44642 & 57460 & 67814 & 79654 & 73709 & 71358 & 66507 & 54734 & 58115 & 55841 & 48586 & 724483 \\
\hline \multicolumn{14}{|l|}{ Consumables articles } \\
\hline \multicolumn{14}{|l|}{ 1. The use of water from s } \\
\hline surface & 5970 & 5993 & 6199 & 6639 & 14451 & 19299 & 19363 & 18652 & 16406 & 6118 & 6004 & 5970 & 131064 \\
\hline ground & 15891 & 15891 & 15891 & 15892 & 17722 & 20433 & 20393 & 20087 & 18986 & 15891 & 15891 & 15891 & 208860 \\
\hline sewage: & 593 & 593 & 593 & 593 & 593 & 593 & 593 & 593 & 593 & 593 & 593 & 593 & 7114 \\
\hline Total Almaty: & 22454 & 22477 & 22683 & 23124 & 32766 & 40325 & 40349 & 39332 & 35984 & 22602 & 22488 & 22454 & 347038 \\
\hline \multicolumn{14}{|l|}{ 2. Transportation losses } \\
\hline TOTAL in Almaty: & 6474 & 6481 & 6543 & 6743 & 9667 & 11936, & 11934 & 11637 & 10650 & 6589 & 6484 & 6474 & 101812 \\
\hline \multicolumn{14}{|c|}{ 3. Losses during surface flow of major rivers: Malaya Almatinka, Vesnovka, Bolshaya Almatinka and Karagaly } \\
\hline Total loss: & 414 & 333 & 403 & 566 & 1209 & 1741 & 1968 & 1730 & 1049 & 696 & 577 & 472 & 11258 \\
\hline \multicolumn{14}{|c|}{ 4. Surface water transfer from the territory of the Almaty city to the other basins through the main channels (MC) } \\
\hline $\begin{array}{l}\text { Total runoff through main } \\
\text { channels: }\end{array}$ & - & - & - & - & 140 & 650 & 768 & 628 & 556 & - & - & - & 2742 \\
\hline \multicolumn{14}{|c|}{ 5. Evaporation from surface water bodies: ponds, stream reservoirs, channels of major rivers (736 mm - apparent evaporation) } \\
\hline $\begin{array}{l}\text { Total evaporation losses } \\
\text { (evaporation - precipitation): }\end{array}$ & - & - & - & - & 72 & 284 & 420 & 436 & 303 & 80 & - & - & 1595 \\
\hline \multicolumn{14}{|c|}{$\begin{array}{l}\text { 6. Precipitation involves the runoff; total evaporation and evaporation from snow and ground surface; evaporation from the water surface; moisture } \\
\text { accumulation due to solid precipitation, followed by runoff during the floods }\end{array}$} \\
\hline \multirow{2}{*}{$\begin{array}{l}\text { Layer and the amount of } \\
\text { precipitation, mm/thousand } \mathrm{m}^{3}\end{array}$} & 29 & 35 & 68 & 99 & 101 & 58 & 39 & 26 & 28 & 54 & 53 & 36 & 626 \\
\hline & 8471 & 10224 & 19863 & 28918 & 29503 & 16941 & 11392 & 7595 & 8179 & 15773 & 15481 & 10516 & 182855 \\
\hline \multicolumn{14}{|c|}{ 7. Regulating releases and environmental flow : major rivers, mountain sources and Karasu } \\
\hline Total releases & 11110 & 9672 & 12455 & 12615 & 12613 & 12597 & 13695 & 11764 & 10666 & 11702 & 11485 & 10874 & 141247 \\
\hline TOTAL DISCHARGE & 42449 & 42705 & 55404 & 65224 & 76302 & 72538 & 68592 & 61483 & 56737 & 50854 & 50032 & 44315 & 686735 \\
\hline \multicolumn{14}{|c|}{ The water balance of the territory of Almaty } \\
\hline Total inflow & 46064 & 44642 & 57460 & 67814 & 79654 & 73709 & 71358 & 66507 & 54734 & 58115 & 55841 & 48586 & 724483 \\
\hline Total discharge & 42449 & 42705 & 55404 & 65224 & 76302 & 72538 & 68592 & 61483 & 56737 & 50854 & 50032 & 44315 & 686735 \\
\hline Water balance & 3615 & 1937 & 2056 & 2590 & 3352 & 1171 & 2766 & 5024 & -2003 & 7261 & 5809 & 4271 & 37748 \\
\hline
\end{tabular}




\section{CONCLUSION}

The territory of Almaty city is located on the foothills loop, formed by the merged fans of small rivers.Ariverfanisazoneofintenseintakeofsurface runoff, irrigation water and precipitation by soil.

They can often move from one position to another while flowing from the mountains to the Ili river valley. If surface runoff or groundwater flow is disturbed by humans, the regime and water balance of both are disturbed.

Intense groundwater pumping in the area for industrial and other needs have a trifold impact on the Karasu:

1. Karasu headwaters move north from the fans;

2. water content of these rivers desceases due to the decrease in springwater outcrop in the channels;

3. seasonal river breathing becomes more quiet.

Intensive urban area re-planning, traffic interchange construction, processes of filling the Karasu valleys and reducing of outflow of water outcrop create the conditions for raising the level of groundwater and flooding buildings in the northern part of the city. The above-mentioned observations prove that there is a need to further study the relationship between the surface and groundvwaters in this area. It also increases the role of studies conducted regarding the channel water balance of small rivers in the city.

\section{REFERENCES}

1. Arhonditsis, G. B., Adams-VanHarn, B. A., Nielsen, L., Stow, C. A., Reckhow, K. H. 2006. Evaluation of the current state of mechanistic aquatic biogeochemical modeling: citation analysis and future perspectives. Environmental Science \& Technology, 40(21), 6547-6554. DOI: 10.1021/es061030q

2. Bacon, M. 2009. Water use efficiency in plant biology. John Wiley \& Sons.

3. Barros, R., Isidoro, D., Aragüés, R. 2011. Long-term water balances in La Violada irrigation district (Spain): I. Sequential assessment and minimization of closing errors. Agricultural Water Management, 102(1), 35-45. https://doi.org/10.1016/j.agwat.2011.10.004

4. Berg, P. A. 2015. The world's need for household water treatment. Journal - American Water Works Association, 107(10), 36-44.

5. Charalambous, K., Bruggeman, A., Lange, M. A. 2012. Assessing the urban water balance: the
Urban Water Flow Model and its application in Cyprus. Water Science and Technology, 66(3), 635-643. DOI: 10.2166/wst.2012.188

6. Chigrinets, A. 2006. The maximum water discharge of Trans-Ili Alatau rivers. Jouranl of Hydrometeorology and Ecology, 3, 93-103.

7. Chigrinets, A.G., Duskaev, K. 2005. The role of the small rivers in solving the problems of water supply in Almaty. Hydrometeorology and Environment., 1, 76-88.

8. Chigrinets, A.G., Dolbeshkin, M.V. 2012. Estimates of the norm of annual runoff on the right bank of the Irtysh river basin. Questions of Geography and Geoecology, Almaty, 2, 62-67.

9. Comair, G. F., McKinney, D. C., Maidment, D. R., Espinoza, G., Sangiredy, H., Fayad, A., Salas, F. R. 2014. GIS-Based System to Better Guide Water Resources Management and Decision Making. In World Environmental and Water Resources Congress 2014: Water Without Borders. ASCE, pp. 1936-1946.

10. Dahl, C., Kuralbayeva, K. 2001. Energy and the environment in Kazakhstan. Energy Policy, 29(6), 429-440.

11. Danilov, V.I., Khranovich, I.L. 2010. Water management. Harmonization of water management strategies. Journal of Scientific World, 14, 229.

12. Duskaev, K., Chigrinets, A.G. 2001. Methodical bases of an estimation of ecological state of small rivers in Almaty. Materials of the Int. Scientificpractical conference "Problems of hydrometeorology and environment, 314-316.

13. Fowe, T., Nouiri, I., Ibrahim, B., Karambiri, H., Paturel, J.-E. 2015. OPTIWAM: an intelligent tool for optimizing irrigation water management in coupled reservoir-groundwater systems. Water Resources Management, 29(10), 3841-3861. https://doi.org/10.1007/s11269-015-1032-9

14. Kennedy, Ch.A., Stewart, I., Facchini, A., Cersosimo, I., Mele, R., Chen, B., Uda, M., Kansal, A., Chiu, A., Kim, K., Dubeux, C., La Rovere, E., Cunha, B., Pincetl, S., Keirstead, J., Barles, S., Pusaka, S., Gunawan, J., Adegbile, M., Nazariha, M., Hoque, Sh., Marcotullio, P.J., Otharán, F.G., Genena, T., Ibrahim, N., Farooqui, R., Cervantes, G., Sahin, A.D. 2015. Energy and material flows of megacities. Proceedings of the National Academy of Sciences, 112(19), 5985-5990. https://doi. org/10.1073/pnas.1504315112

15. Luo, Y. F., Khan, S., Cui, Y. L., Feng, Y. H., Li, Y. L. 2005. Modeling the water balance for aerobic rice: A system dynamics approach. In MODSIM05 - International Congress on Modelling and Simulation: Advances and Applications for Management and Decision Making, Proceedings, pp. 1860-1866. 
16. Mambretti, S., Brebbia, C. A. 2012. Urban Water. WIT Press.

17. Mynbaeva, B. N. 2016. Almaty city river monitoring of heavy metal pollution. Journal Sections, 95(95).

18. Nouiri, I., Yitayew, M., Maßmann, J., Tarhouni, J. 2015. Multi-objective optimization tool for integrated groundwater management. Water Resources Management, 29(14), 5353-5375. https://doi.org/10.1007/s11269-015-1122-8

19. Ospanov, K. T., Myrzakhmetov, M. M., Zholguttiyev, B. B. 2015. Ecological Status of Sludge Drying Beds Almaty, Kazakhstan. Methods, 7(8), 9.

20. Ouyang, Y., Wentz, E. A., Ruddell, B. L., Harlan, S. L. 2014. A Multi-Scale Analysis of Single-Family Residential Water Use in the Phoenix Metropolitan Area. JAWRA Journal of the American Water Resources Association, 50(2), 448-467. https://doi. org/10.1111/jawr.12133

21. Paterson, W., Rushforth, R., Ruddell, B. L., Konar, M., Ahams, I. C., Gironás, J., Mijic, A., Mejia, A. 2015. Water footprint of cities: A review and suggestions for future research. Sustainability, 7(7), 8461-8490. https://doi.org/10.3390/su7078461

22. Protasov, V.F. 1999. Ecology, health and environmental protection in Russia. Journal of Finance and Statistics, 2, 36-38.

23. Rawaf, S., De Maeseneer, J., Starfield, B. 2008. From Alma-Ata to Almaty: a new start for primary health care. The Lancet, 372(9647), 1365-1367. DOI: 10.1016/S0140-6736(08)61524-X

24. Ruddell, B. L., Adams, E. A., Rushforth, R., Tidwell, V. C. 2014. Embedded resource accounting for coupled natural-human systems: An application to water resource impacts of the western US electrical energy trade. Water
Resources Research, 50(10), 7957-7972. https:// doi.org/10.1002/2013WR014531

25. Rushforth, R. R., Adams, E. A., Ruddell, B. L. 2013. Generalizing ecological, water and carbon footprint methods and their worldview assumptions using Embedded Resource Accounting. Water Resources and Industry, 1, 77-90. https://doi. org/10.1016/j.wri.2013.05.001

26. Seto, K. C., Reenberg, A., Boone, C. G., Fragkias, M., Haase, D., Langanke, T., Marcotullio, P., Munroe, D.K., Olah, B., Simon, D. 2012. Urban land teleconnections and sustainability. Proceedings of the National Academy of Sciences, 109(20), 76877692. https://doi.org/10.1073/pnas.1117622109

27. Starke, P., Wallmeyer, C., Rölver, S., Göbel, P., Coldewey, W. G. 2011. Development of a new laboratory evaporation measurement device as decision support for evaporation-optimized building. Building and Environment, 46(12), 2552-2561. https://doi.org/10.1016/j.buildenv.2011.06.010

28. Taghvaeian, S., Neale, C. M. 2011. Water balance of irrigated areas: a remote sensing approach. Hydrological Processes, 25(26), 4132-4141. https:// doi.org/10.1002/hyp.8371

29. Tsoukalas, I., Makropoulos, C. 2015. A surrogate based optimization approach for the development of uncertainty-aware reservoir operational rules: the case of nestos hydrosystem. Water Resources Management, 29(13), 4719-4734. https://doi.org/10.1007/s11269-015-1086-8

30. Wang, Q. J., Pagano, T. C., Zhou, S. L., Hapuarachchi, H. A. P., Zhang, L., Robertson, D. E. 2011. Monthly versus daily water balance models in simulating monthly runoff. Journal of Hydrology, 404(3-4), 166-175. https://doi.org/10.1016/j. jhydrol.2011.04.027 